\title{
LEGILINGWISTYCZNE BADANIA KONTRASTYWNE W POLSCE NA PRZYKLADZIE PARY JĘZYKÓW KOREAŃSKI - POLSKI
}

\section{Artur Dariusz KUBACKI, prof. UP dr hab.}

Instytut Neofilologii

Uniwersytet Pedagogiczny im. Komisji Edukacji Narodowej

w Krakowie

ul. Studencka 5, 31-116 Kraków

kubart@post.pl

https://orcid.org/0000-0002-3740-2551

Recenzja nieopublikowanej rozprawy doktorskiej pt.

Umowy prawa cywilnego w przekładzie koreańsko-polskim

i polsko-koreańskim oraz opublikowanych artykułów

legilingwistycznych

autorstwa Emilii Wojtasik-Dziekan

W 2018 roku mgr Emilia Wojtasik-Dziekan, badaczka i wykładowczyni ówczesnego Zakładu Filologii Koreańskiej, obroniła 
na Wydziale Neofilologii Uniwersytetu im. Adama Mickiewicza w Poznaniu rozprawę doktorską pt. Umowy prawa cywilnego w przekładzie koreańsko-polskim i polsko-koreańskim, którą napisała pod kierunkiem prof. UAM dra hab. Kyong-Geuna Oh, i otrzymała stopień doktora nauk humanistycznych w zakresie językoznawstwa porównawczego.

Przygotowywana przez nią do druku dysertacja doktorska ${ }^{1}$ jest nowatorskim opracowaniem interdyscyplinarnym, które doskonale wpisuje się $\mathrm{W}$ nurt badań legilingwistyki, tj. nauki zajmującej się badaniem języka prawnego i prawniczego z wykorzystaniem wiedzy i metodologii językoznawczej. Nauka ta między innymi przez Jerzego Pieńkosa (1999: 3) oraz Macieja Malinowskiego (2018: 13) określana jest mianem juryslingwistyki (jurilinguistique) $^{2}$, a termin ten po raz pierwszy wprowadził do nauki Jean-Claude Gémar w latach 70. XX wieku w Kanadzie. Dziedzinę badań stanowiących przedmiot recenzowanej rozprawy doktorskiej monografii można by nawet określić mianem ,jurytranslatoryki” lub „legitranslatoryki”, ponieważ w jej przypadku wykorzystano między innymi teorię skoposu Hansa Vermeera (1978: 99-102) oraz metodę przekładu pragmatycznego Danuty Kierzkowskiej (2002: 12) do badań nad tłumaczeniem koreańskich i polskich tekstów języka prawa, a wyprowadzone $\mathrm{z}$ analizy wnioski są niezwykle cenne

\footnotetext{
${ }^{1}$ Recenzentami wysoko ocenionej rozprawy doktorskiej byli prof. Romuald Huszcza oraz autor niniejszego artykułu recenzyjnego. Rozprawa doktorska liczy 510 stron, natomiast wersja przeznaczona do publikacji zostanie przez Autorkę znacznie skrócona. Przygotowywana do druku rozprawa doktorska była także przedmiotem wnikliwej recenzji wydawniczej mojego autorstwa.

${ }^{2}$ Termin ten w błędnej formie językowej wprowadził do obiegu naukowego Jerzy Pieńkos (1999), natomiast na błędne użycie członu określającego terminu juryslingwistyka w wymienionym złożeniu zwraca konsekwentnie uwagę Aleksandra Matulewska, redaktorka naczelna czasopisma Comparative Legilinguistics. International Journal for Legal Communication. Jej zdaniem prawidłowa pod względem językowym forma to jurylingwistyka, co notabene potwierdza także strukturalnie termin francuski jurilinguistique. Niestety, błąd ten powielany jest we wszystkich artykułach naukowych oraz książkach, w których podejmuje się problematykę badań legilingwistycznych, określając je mianem juryslingwistyki (zob. recenzja monografii naukowej Macieja Malinowskiego w tym samym tomie czasopisma). Nawet sądy okręgowe w Polsce powołują biegłych w zakresie juryslingwistyki (zob. lista biegłych sądowych przy Sądzie Okręgowym w Gdańsku).
} 


\section{Comparative Legilinguistics 40/2019}

dla translodydaktyki ${ }^{3}$ oraz praktyki thumaczenia specjalistycznego. Szkoda, że Ministerstwo Nauki i Szkolnictwa Wyższego - mimo wielu starań ze strony środowiska naukowego oraz powstawania wielu prac naukowych poświęconych sztuce tłumaczenia - nie chce nadal uznać translatoryki za odrębną dyscyplinę w ramach dziedziny nauk humanistycznych.

Dysertacja doktorska Emilii Wojtasik-Dziekan obejmuje wprowadzenie, cztery rozdziały, zakończenie, bibliografię oraz następujące wykazy: wykaz skrótów użytych w pracy, wykaz źródeł prawa polskiego i koreańskiego, a także wykaz rysunków i tabel. Ponadto w skład pracy weszło streszczenie w języku polskim i angielskim. Układ rozprawy odzwierciedla klasyczny podział na część teoretyczną i empiryczną, do których przynależą po dwa rozdziały.

Zamierzeniem naukowym Emilii Wojtasik-Dziekan jak sama podaje we Wprowadzeniu - były analiza porównawcza polskiego i koreańskiego języka prawa w celu wykazania obecności określonych cech $\mathrm{w}$ języku prawa obu tych krajów oraz analiza komparatystyczna tekstów prawniczych (umów cywilnych) w kontekście traduktologicznym, której rezultatem będzie utworzenie bazy terminologicznej. Korpus badawczy stanowią koreańskie i polskie umowy cywilne oraz ogólnodostępne wzorce umów ze szczególnym uwzględnieniem umów przenoszących prawo własności: sprzedaży, najmu, dzierżawy i darowizny (nie podano jednak ram czasowych, jakie obejmują analizowane w opracowaniu umowy). Wymienione rodzaje umów zostały poddane szczegółowej analizie na podstawie przepisów polskiego i koreańskiego Kodeksu cywilnego. Oprócz wyżej wymienionych głównych metod badawczych posłużono się także metodą analizy tekstów porównywalnych, a także przeprowadzono szczegółową analizę bogatej literatury z zakresu prawa polskiego i koreańskiego.

Teoretyczną część pracy otwiera rozdział, w którym szczegółowo przedstawiono stan badań w zakresie

\footnotetext{
${ }^{3}$ Termin ten został zaproponowany przez Monikę Płużyczkę (2009) z Uniwersytetu Warszawskiego i wszedł na stałe do obiegu naukowego. W Katedrze Językoznawstwa Niemieckiego Instytutu Neofilologii Uniwersytetu Pedagogicznego im. Komisji Edukacji Narodowej w Krakowie powstała w 2018 r. seria wydawnicza pt. Wybrane zagadnienia $z$ glotto- $i$ translodydaktyki pod red. Artura D. Kubackiego i Katarzyny Sowy-Baci.
} 
przekładoznawstwa i legilingwistyki. Autorka koncentruje się w nim na omówieniu języka specjalistycznego, a w szczególności języka prawa, jego cech i klasyfikacji. Następnie referuje zagadnienia przekładoznawcze w kontekście sądowym, prawnym i prawniczym. Skupia się na różnych koncepcjach przekładu prawniczego, tj. między innymi na koncepcji Marcina Lutra, Friedricha Schleiermachera, Hansa Vermeera, Christiane Nord, Olgierda Wojtasiewicza, Danuty Kierzkowskiej, a później przedstawia problem ekwiwalencji, omawia etapy przekładu i konsekwencje ich naruszenia.

W drugim rozdziale Autorka bierze pod lupę język prawa w Polsce i Korei Południowej. Najpierw referuje historię rozwoju tych języków i badań nad nimi w obu krajach, a następnie omawia w ujęciu kontrastywnym takie fenomeny, jak terminologia, zapożyczenia, neologizmy, polisemy, homonimy, homofony i homografy, metafory, eufemizmy, archaizmy, wulgaryzmy, nominalizacja, słowotwórstwo, wyrażenia przyimkowe, partykuły i rekcja czasownikowa, określenia czasu, modalność deontyczna i sposoby jej wyrażania oraz cechy języka prawa na poziomie zdania.

Część analityczną otwiera rozdział trzeci, poświęcony ogólnym zagadnieniom koreańskich i polskich zobowiązań umownych w aspekcie komparatystycznym. Natomiast w części szczegółowej tego rozdziału przedstawiono i zreferowano - także pod kątem porównawczym - umowy cywilne z Polski i Korei (tj. umowę sprzedaży, najmu i dzierżawy, o dzieło i zlecenia oraz darowizny), a także poczyniono wstępne ustalenia terminologiczne. Punktem odniesienia jest polski Kodeks cywilny, natomiast analizie poddano kluczowe elementy zobowiązań dla wymienionych powyżej umów.

Ostatni rozdział pracy doktorskiej zawiera szczegółową analizę wyżej wymienionych umów cywilnoprawnych z obu krajów $\mathrm{W}$ aspekcie translatologicznym ${ }^{4}$. Badając komparatystycznie strukturę umów, Autorka wskazuje na charakterystyczne związki frazeologiczne, typową strukturę składniową wypowiedzi oraz różnice kulturowe, a ponadto proponuje autorskie rozwiązania translatorskie. Przedmiotem analizy było w sumie piętnaście klauzul umownych oraz podpisy stron umowy.

\footnotetext{
${ }^{4}$ Terminy translatologiczny, traduktologiczny, translatoryczny i przekładoznawczy traktuję w niniejszym artykule synonimicznie.
} 


\section{Comparative Legilinguistics 40/2019}

Oceniając merytorycznie recenzowaną rozprawę, należy wyraźnie podkreślić, że Emilia Wojtasik-Dziekan jest znakomicie oczytana zarówno w polskiej, jak i obcojęzycznej literaturze przedmiotu dotyczącej najnowszych badań legilingwistycznych i translatorycznych. Oprócz najnowszych opracowań polskich i koreańskich badaczy Autorka powołuje się często na aktualne źródła anglo- i niemieckojęzyczne. Co więcej, nie boi się wyrażania krytyki, a także formułowania własnych uwag i wyciągania wniosków translacyjnych. Na szczególną pochwałę zasługują ciekawe uwagi kontrastywne $\mathrm{w}$ odniesieniu do dziedziny prawa cywilnego. Widać, że Autorka nie tylko porusza się z dość dużą swobodą w tej dziedzinie i posiada spore umiejętności $\mathrm{w}$ zakresie komparatystyki prawnej, ale także potwierdza swoje wysokie kompetencje thumaczeniowe, przekładając świetnie na język polski zarówno literaturę obcojęzyczną (koreańską, rosyjską, niemiecką i angielską) z zakresu językoznawstwa i prawa, jak i analizowane fragmenty umów koreańskich, co potrafię ocenić na podstawie wieloletniej praktyki w wykonywaniu zawodu tłumacza przysięgłego. Uzyskane przez Emilię Wojtasik-Dziekan wyniki badań mają dużą wartość aplikatywną dla translodydaktyki akademickiej oraz stanowią znaczący wkład w zakresie prakseologii thumaczenia koreańskopolskiego i polsko-koreańskiego z zakresu prawa. I tak na przykład $\mathrm{z}$ dużym zainteresowaniem przeczytałem fragmenty pracy poświęcone zawodowi oraz kompetencjom tłumacza przysięgłego i sądowego w Polsce i Korei, ponieważ tego typu eksplikacje są bardzo cenne ze względu na brak informacji w Polsce o tym zawodzie w krajach azjatyckich.

Podsumujmy zatem w punktach zalety dysertacji doktorskiej Emilii Wojtasik-Dziekan. Jej praca:

- wypełnia lukę w badaniach traduktologicznych w zakresie thumaczenia specjalistycznego $\mathrm{z}$ zakresu prawa w parze językowej koreański-polski;

- $\quad$ stanowi nowatorską analizę komparatystyczną polskiego i koreańskiego języka prawa oraz tekstów umów cywilnych $\mathrm{z}$ obu krajów $\mathrm{w}$ celu wypracowania bazy terminologicznej między innymi dla thumaczy;

- $\quad$ charakteryzuje się selektywnym przedstawieniem głównych koncepcji translatorycznych w kontekście legilingwistyki, co stanowi punkt wyjścia 
do przeprowadzonych przez Autorkę analiz w części empirycznej pracy;

- $\quad$ zawiera klarowną i bogato zilustrowaną analizę polskich i koreańskich umów cywilnych w aspekcie traduktologicznym ze szczególnym uwzględnieniem charakterystycznych związków frazeologicznych, typowych struktur składniowych oraz różnic kulturowych;

- przynosi autorskie rozwiązania translatorskie świadczące o dużym doświadczeniu Autorki w roli pośrednika językowego;

- $\quad$ nie pomija osiągnięć polskiej nauki w zakresie myśli translatorycznej.

Rozprawa doktorska Emilii Wojtasik-Dziekan pod tytułem Umowy prawa cywilnego $w$ przektadzie koreańsko-polskim i polskokoreańskim ma charakter pionierski w zakresie porównawczych badań legilingwistycznych $\mathrm{w}$ Polsce $\mathrm{i} \mathrm{z}$ tego powodu warto ją polecić szerokiemu gronu odbiorców, a przede wszystkim adeptom sztuki przekładu tekstów specjalistycznych $\mathrm{z}$ zakresu prawa cywilnego pracujących w parze języków koreański - polski.

Na koniec warto jeszcze wymienić i skomentować cykl pięciu opublikowanych artykułów autorstwa Emilii Wojtasik-Dziekan odnoszących się do kontrastywnych badań legilingwistycznych w parze językowej koreański - polski (2014a, 2015, 2016a, 2016b, 2019).

W wymienionych publikacjach Autorka dokonała przede wszystkim szczegółowych analiz komparatystycznych wybranych terminów z zakresu prawa zobowiązań (np. użyczenie, pożyczka) bądź z zakresu prawa rzeczowego (np. własność, współwłasność, nieruchomość, użytkowanie wieczyste, służebność). Analizy porównawcze dotyczyły również kluczowych regulacji występujących w konkretnych umowach cywilnych (np. klauzule w umowach najmu) w aspekcie translatorycznym. Przedmiotem refleksji przekładoznawczej była także polska terminologia ustawowa w zakresie nazewnictwa umów i ich stron względem nomenklatury koreańskiej $\mathrm{w}$ tym zakresie. Na szczególne uznanie zasługuje najnowszy artykuł Emilii Wojtasik-Dziekan (2019) dotyczący statusu prawnego kobiet $\mathrm{w}$ południowokoreańskim i polskim ustawodawstwie rodzinnym. Autorka przeprowadziła w nim ciekawą analizę porównawczą obecnego stanu prawnego w Korei Południowej 


\section{Comparative Legilinguistics 40/2019}

i Polsce w kontekście obowiązujących współcześnie regulacji dotyczących prawa rodzinnego ze szczególnym uwzględnieniem jednostkowych praw kobiet (analizie poddano przykładowo przepisy związane $\mathrm{z}$ zawieraniem małżeństwa, regulacje majątkowe, unieważnienie związku małżeńskiego lub rozwiązanie małżeństwa przez rozwód, rodzicielstwo, opieka nad dziećmi). Za podstawę analizy kontrastywnej posłużyły odnośne przepisy konstytucji oraz właściwych kodeksów obydwu krajów, przy czym Autorka uwzględniła przy tym niezwykle ważne tło kulturowo-historyczne obu porównywanych systemów prawnych.

Poza problematyką przekładoznawczą w kręgu zainteresowań badawczych Emilii Wojtasik-Dziekan znajdują się proces kształtowania się prawa i jego języka w Korei (2014b) oraz uwarunkowania historyczno-kulturowe zwrotów pochodzenia chińskiego używanych w języku koreańskim (2009). Do najważniejszych czynników zewnętrznych formujących prawo w Korei badaczka zaliczyła uwarunkowania historyczne i sytuację polityczną, ale także dostrzegła w tym zakresie rolę wpływów kulturowych i religijnych. W ramach badań diachronicznych uczona przeanalizowała nie tylko wybrane koreańskie akty prawne, ale także omówiła zarówno poszczególne terminy prawa koreańskiego, jak i ich pojawianie się w rzeczywistości prawnej państw koreańskich. Historia formowania się języka prawa w Korei została ujęta chronologicznie i posłużyła do zaprezentowania procesu zapożyczeń w prawnej i prawniczej warstwie języka koreańskiego jako jednej $\mathrm{z}$ cech języka prawa.

W tym kontekście warto także wspomnieć o kontrastywnych badaniach legilingwistycznych trzech innych badaczy z Uniwersytetu im. Adama Mickiewicza w Poznaniu, którzy również zajmowali się problematyką przekładu w parze językowej koreański - polski. Są nimi mgr Bernadetta Bałazy, prof. UAM Aleksandra Matulewska oraz wspominany powyżej polonista i koreanista prof. UAM KyongGeun Oh.

Bernadetta Bałazy (2015) podjęła się próby tłumaczenia nazewnictwa kar w odniesieniu do koreańsko-polskiej pary językowej. Aleksandra Matulewska i Kyong-Geun Oh (2016;) w jednym wspólnym artykule naukowym przedstawili sposoby wyrażania modalności deontycznej w tekstach polskiego i koreańskiego Kodeksu cywilnego, zaś w 2017 roku razem z Darią Zozulą przyjrzeli się deontyce modalnej $\mathrm{w}$ prawie cywilnym $\mathrm{w}$ zestawieniu czterech 
języków: polskiego, angielskiego, indonezyjskiego i koreańskiego Ponadto Kyong-Geun Oh (2015) opublikował jeden tekst na temat ewolucji języka urzędowego w Korei.

Podsumowując: wiodącym ośrodkiem w zakresie badań legilingwistycznych pozostaje bez wątpienia Wydział Neofilologii Uniwersytetu im. Adama Mickiewicza w Poznaniu, który przed 30.09.2019 r., tj. przed zmianą struktury uczelni zgodnie $\mathrm{z}$ reformą szkolnictwa wyższego z 2018/2019 r., gromadził badaczy języka prawa w różnych kombinacjach językowych wokół Zakładu Legilingwistyki i Języków Specjalistycznych, kierowanego przez prof. UAM Aleksandrę Matulewską ${ }^{5}$. Wśród wymienionych powyżej naukowców $\mathrm{W}$ zakresie legilingwistycznych badań koreańskopolskich na plan pierwszy wysuwa się dr Emilia Wojtasik-Dziekan, która - będąc czynnym tłumaczem pisemnym i ustnym języka koreańskiego - zajęła się naukowo koreańskim językiem prawnym i prawniczym. Przeprowadzone przez nią lingwistyczne analizy porównawcze prawa Korei i Polski zaowocowały opublikowaniem kilku artykułów oraz obroną doktoratu, a w konsekwencji tych działań naukowych przygotowywaniem książki poświęconej umowom prawa cywilnego w przekładzie koreańsko-polskim i polsko-koreańskim. Zarówno napisana dysertacja doktorska, jak i opublikowane artykuły prezentują wysoki poziom merytoryczny i poruszają aspekty, które dotychczas nie były jeszcze przedmiotem refleksji naukowej. Teksty te zawierają unikatowe rozważania teoretyczne i cenne analizy praktyczne, które z pewnością zainteresują zwłaszcza studentów filologii koreańskiej oraz czynnych tłumaczy języka koreańskiego.

\footnotetext{
${ }^{5}$ Zob. recenzja badań naukowców z Instytutu Językoznawstwa UAM w Poznaniu w zakresie zastosowania metody parametryzacji $\mathrm{w}$ analizie ekwiwalencji terminów prawnych $\mathrm{w}$ dziedzinie prawa cywilnego materialnego i procesowego $\mathrm{w}$ odniesieniu do języka polskiego i innych języków, tj. angielskiego, chińskiego, greckiego, hiszpańskiego, szwedzkiego i węgierskiego - w: Kubacki, Artur Dariusz. 2017. $\mathrm{Z}$ najnowszych badań legilingwistycznych w Polsce. Comparative Legilinguistics. International Journal for Legal Communication 31. s. 167-172.
} 


\section{Bibliografia}

Bałazy, Bernadetta. 2015. Nazewnictwo kar w Kodeksie karnym Republiki Korei w aspekcie tłumaczeniowym koreańskopolskim. Comparative Legilinguistics. International Journal for Legal Communication vol. 22. 43-63.

Gémar, Jean-Claude. 1982. Langage du droit et traduction. Essai de jurilinguistique. The Language of the Law and Translation. Essays on Jurilinguistics. Québec-Montréal: Linguatech Conseil de la langue française.

Kierzkowska, Danuta. 2002. Ttumaczenie prawnicze. Warszawa: Wydawnictwo TEPIS Polskiego Towarzystwa Tłumaczy Ekonomicznych, Prawniczych i Sądowych.

Kubacki, Artur Dariusz. 2017. Z najnowszych badań legilingwistycznych w Polsce. Comparative Legilinguistics. International Journal for Legal Communication 31. s. 167172.

Malinowski, Maciej. 2018. Polszczyzna. O większa poprawność językowa tekstów prawniczych $i$ nie tylko. Kraków: Wydawnictwo-Drukarnia Ekodruk s.c.

Matulewska, Aleksandra i Kyong-Geun Oh. 2016. Środki wyrażania nakazu w polskim i koreańskim Kodeksie cywilnym. W Język polskiego prawa: nowe wyzwania, red. Dorota KondratczykPrzybylska, Adam Niewiadomski i Ewa Walewska. Warszawa: Zakład Graficzny Uniwersytetu Warszawskiego. $165-184$.

Matulewska, Aleksandra, Kyong-Geun Oh i Daria Zozula. 2017. Exponents of Deontic Modality in Korean, Indonesian, English and Polish: A Contrastive Translative Perspective. Rocznik Orientalistyczny t. LXX, z. 2. 185-211.

Oh, Kyong-Geun. 2015. Ewolucja języka urzędowego w Korei. Comparative Legilinguistics. International Journal for Legal Communication 22. 65-77.

Pieńkos, Jerzy. 1999. Podstawy juryslingwistyki. Język w prawie prawo w języku. Kraków: Oficyna Prawnicza Muza SA.

Płużyczka, Monika. 2009. Dydaktyka translacji - rozważania terminologiczne. Przeglad Glottodydaktyczny 26. 195-200.

Vermeer, Hans. 1978. Ein Rahmen für eine allgemeine Translationstheorie. Lebende Sprachen 3. 99-102. 
Wojtasik, Emilia 2009. Hanja/Saja/Gosa Seongeo (한자/사자/고사성어) - powiedzenia i zwroty pochodzenia chińskiego w języku koreańskim - uwarunkowania historyczno-kulturowe. W $\quad Z$ zagadnień leksykalnosemantycznych. Wokót stów i znaczeń III. Materiały trzeciej konferencji językoznawczej poświęconej pamięci prof. Bogustawa Krei, red. Beata Milewska i Sylwia Rzedzicka. Gdańsk: Wydawnictwo Uniwersytetu Gdańskiego. 337-342.

Wojtasik, Emilia. 2014a. Klauzula dotycząca przedmiotu umowy najmu w języku koreańskim i polskim w aspekcie translacyjnym. Comparative Legilinguistics. International Journal for Legal Communication 17. 145-162.

Wojtasik, Emilia. 2014b. Przyczynek do historii rozwoju prawa i lingua legis $\mathrm{w}$ Korei. Investigationes Linguisticae vol. XXXI. 43-56.

Wojtasik, Emilia. 2015. Problemy przekładu prawniczego koreańskopolskiego na przykładzie terminów użyczenie i pożyczka. W Język polskiego prawa: perspektywa europejska, red. Dorota Kondratczyk-Przybylska, Adam Niewiadomski i Ewa Walewska. Warszawa: Zakład Graficzny Uniwersytetu Warszawskiego. 253-262.

Wojtasik, Emilia. 2016a. Polsko-koreańska terminologia ustawowa w zakresie nazewnictwa umów i ich stron. W Język polskiego prawa: nowe wyzwania, red. Dorota Kondratczyk-Przybylska, Adam Niewiadomski i Ewa Walewska. Warszawa: Zakład Graficzny Uniwersytetu Warszawskiego. 263-276.

Wojtasik-Dziekan, Emilia. 2016b. Wybrana terminologia z zakresu prawa rzeczowego w przekładzie polsko-koreańskim. W Przyszłość zawodu thumacza przysięgłego i specjalistycznego - wspótczesne wyzwania, red. Marta Czyżewska i Aleksandra Matulewska. Warszawa: Polskie Towarzystwo Tłumaczy Przysięgłych i Specjalistycznych TEPIS. 245-266.

Wojtasik-Dziekan, Emilia. 2019. Zarys statusu prawnego kobiet w południowokoreańskim i polskim ustawodawstwie rodzinnym. W Koreańskie światy kobiet między dziedzictwem konfucjanizmu a wyzwaniami współczesności, red. Romuald Huszcza, Justyna Najbar-Miller i Anna WojakowskaKurowska. Warszawa: Wydawnictwa Uniwersytetu Warszawskiego. 201-222. 
Comparative Legilinguistics 40/2019

\section{Źródła internetowe:}

Lista biegłych sądowych przy Sądzie Okręgowym w Gdańsku:

http://www.gdansk.so.gov.pl/lista-bieglych-sadowych (dostęp 03.12.2019 r.). 